DOI 10.18551/rjoas.2020-05.12

\title{
ANALYSIS OF PRIME FISHING UNITS IN WEST MANGGARAI DISTRICT, EAST NUSA TENGGARA, INDONESIA
}

\author{
Sadir Edizul Adiwijaya ${ }^{1,2^{*}}$, Nainggolan Chandra ${ }^{1}$, Sutisna Dedy $\mathbf{H}^{1}$ \\ ${ }^{1}$ Department Fishing Technology, Faculty Fishing Technology, Jakarta Fisheries University, \\ Jakarta, Indonesia \\ ${ }^{2}$ Center for Marine and Fisheries Education, Senior Highschool Fisheries of Business, \\ Kupang, Indonesia \\ *E-mail: edizulsadir@gmail.com
}

\begin{abstract}
West Manggarai Regency is an area in the province of East Nusa Tenggara with various types of fishing equipment operated by fishermen. The types of fishing gear have their own impact on the available resources and economy so a study of the types of fishing gear that is worth prioritizing needs to be done. The research objective is to choose the type of fishing technology that deserves to be prioritized to be developed in the waters of West Manggarai Regency by considering biological, technical, social and economic aspects, as well as looking at superior fish resources. The study was conducted using survey methods and field observations Data sources obtained in this study were data and information from respondents through interviews with questionnaires or questionnaires. Analysis of the data in this study is a scoring method (multi criteria analysis) with a value function as a standardized value. The approach used in multi criteria analysis is biological, technical, social and economic aspects. The results showed trawl ring occupies the first priority in the category of technical, biological, and social aspects. Boat charts occupy the first priority of financial feasibility (economic aspects). Based on the results of a total standardization analysis of the technical, biological, social, economic aspects of the capture unit in West Manggarai Regency the development priority is the trawling ring capture unit.
\end{abstract}

\section{KEY WORDS}

Fishing unit, aspect technical, biological, social, economic, value functions.

The use of fishing technology in fisheries management is carried out with the precautionary principle so that resources can be used sustainably (Wiadnya et al. 2017). Optimal use of fish resources by fishermen must be supported by the fishing gear technology used. The main purpose of choosing an appropriate fishing unit is to develop capture fisheries to empower fishermen. Appropriate fishing unit: 1) if viewed in terms of biological capture technology that will be developed does not damage or interfere with the preservation of resources, 2) is technically effectively used, 3) socially acceptable to the fishing community and 4) economically the technology is profitable (Wulandari et al. 2017).

West Manggarai Regency is an area that has several types of fish catching equipment. However, some types of fishing gear have advantages and disadvantages both technically, biologically, socially, and economically. This causes the management of fish resources at sea to be suboptimal because it is clear that the existing capture tools have not been identified for their impacts on aspects that are important for the sustainability of resources and the economy of fishing communities. So it is necessary to study the selection of priority fishing tools that can be developed in the future so that stakeholders can be more focused and easier to manage and manage existing fish resources.

The purpose of this study is to choose the type of fishing technology that deserves to be prioritized for development in the waters of West Manggarai Regency by considering biological, technical, social and economic aspects. And see excellent fish resources.

The benefits that can be obtained from this study for the fishing community are that it can be used as a material consideration in the selection of superior fishing equipment in terms of technological, biological, social and economic aspects. Then the benefits for the 
government can be used as reference material for the development of capture fisheries based on sustainable fishing gear technology.

\section{METHODS OF RESEARCH}

The research was carried out in West Manggarai Regency for three months starting from August to October 2019. The location of the study was carried out at the Labuan Bajo Fish Auction Place (FAP) in Komodo District. The method is survey research method and field observations. This research is a comparative study. Comparisons were made of biological, technical, social, and economic aspects between lift net, handline, gill nets, purse seine, and seine beach.

Data collection is done by measurement and direct observation of the research location. Data collected for each aspect of the study are:

- Technical aspects. The technical parameters collected are ease of operation of fishing gear, the capability of operating range of fishing gear (nautical miles), the selectivity of fishing gear, the productivity of fishing gear (CPUE) (Mahiswara et al. 2016);

- Biological aspects. Biological parameters collected include the length of the day of capture (trip), the composition of the catch, the size of the fish that is often caught, and the length of the fishing season (Iswara et al. 2014);

- Economic aspects. The economic parameters collected are investment costs, operational costs, maintenance costs, and production value and financial aspects. The collected financial parameters are NPV, B / C Ratio, IRR (Antika et al. 2014);

- Social Aspects. The social parameters collected are labor absorption, wages received by workers, level of technological mastery, fishing gear accepted by the community (Irham, 2013).

The data analysis method in this research is the MCA (multi-criteria analysis) scoring method. Where the MCA method is a method of overall decision making over a number of mixed aspects or parameters (Syaukani et al. 2017; Setiawan et al. 2007; Heriawan, 2008; dan Damanik et al. 2016). The approach used in the multi-criteria analysis is biological, technical, social, and economic aspects. The criteria used in this analysis were modified from Suman (2017).

Scoring is given from the lowest value to the highest. For the highest value given priority order one as so on. An assessment of all criteria or aspects is used in exchange rates. So all values have the same standard. The type of fishing gear that gets the highest value is better than the others, and vice versa. Standardization value functions can be done by using the formula fromn (Septifitri et al. 2010) as follows:

$$
\begin{aligned}
& V(x)=\frac{X-X 0}{X i-X 0} \\
& \mathrm{~V}(\mathrm{~A})=\sum_{i=1}^{n} V i(X i)
\end{aligned}
$$

For $\mathrm{i}=1,2,3, \ldots, \mathrm{n}$

$V(x)=$ The value function of the variable $x$;

$X=$ Variable $x$;

$X O=$ The worst value is the criterion $x$;

$V(A)=$ The value function of alternative $A$;

$V i(X i)=$ The value function of the alternatives to the i criterion

$X i=$ Criteria $i$

\section{RESULTS AND DISCUSSION}

The research results obtained are explained based on each aspect, where every aspect has a different value to each fish catcher. Then from these aspects are tabulated and 
calculated in a comprehensive manner to determine the value that can answer for the assessment which can be a development priority

The results of the analysis of the technical aspects obtained from observations and interviews with fishermen at West Manggarai Regency area is presented full in Table 1.

Table 1 - Assessment Analysis of technical aspects

\begin{tabular}{clcccccccccc}
\hline \multirow{2}{*}{ No } & \multirow{2}{*}{ Fishing Gear } & \multicolumn{7}{c}{ Technical Aspects } & \multicolumn{2}{c}{$\mathrm{V}(\mathrm{A})_{1}$} & \multirow{2}{*}{$\mathrm{OP}$} \\
\cline { 3 - 8 } & & $\mathrm{X} 1$ & $\mathrm{~V}_{1}\left(\mathrm{X}_{1}\right)$ & $\mathrm{X} 2$ & $\mathrm{~V}_{2}\left(\mathrm{X}_{2}\right)$ & $\mathrm{X} 3$ & $\mathrm{~V}_{3}\left(\mathrm{X}_{3}\right)$ & $\mathrm{X} 4$ & $\mathrm{~V}_{4}\left(\mathrm{X}_{4}\right)$ & & \\
\hline 1 & Lift net & 4,55 & 1,00 & 2,72 & 0,39 & 3,93 & 0,91 & 153,33 & 0,38 & 2,68 & 2 \\
2 & Gill net & 4,33 & 0,94 & 2,46 & 0,09 & 3,38 & 0,18 & 68,67 & 0,13 & 1,34 & 3 \\
3 & Purse seine & 1,00 & 0,00 & 3,25 & 1,00 & 4,00 & 1,00 & 361,67 & 1,00 & 3,00 & 1 \\
4 & Line fishing & 4,38 & 0,95 & 2,38 & 0,00 & 3,48 & 0,32 & 25,33 & 0,00 & 1,27 & 4 \\
5 & Seine beach & 3,15 & 0,61 & 2,41 & 0,03 & 3,24 & 0,00 & 76,00 & 0,15 & 0,79 & 5 \\
\hline
\end{tabular}

Source: Research data processed, 2019.

Note:

$\mathrm{X} 1$ : Ease of operation of fishing gear;

X2: Capability of capture unit operations (nautical miles);

X3: Fishing gear selectivity (target / non-target fishing);

X4: Fishing gear productivity (CPUE value);

$\mathrm{Vi}(\mathrm{Xi)}$ : The value function of alternative $\mathrm{Xi}$;

$\mathrm{V}(\mathrm{A})$ : The value function of alternative $\mathrm{A}$, which is the sum of $\mathrm{Vi}(\mathrm{Xi})$;

OP: Priority order.

Table 1 The assessment of excellence based on technical aspects, placing the purse seine capture unit on the priority the aspects of the reach of capture operations, fishing gear selectivity, and high productivity, with a standard value of 1.00. from the aspect of ease of operation, line fishing gear is in the order of priority with a standard value of 1.00 . Standardization of technical aspects criteria by using the value function against all assessment criteria, placing purse seine in first, second lift net, followed by line fishing tools, fourth-gill net, and beach seine in the last sequence.

The assessment of the biological aspects of the fishing unit is focused on four criteria, namely, the length of the fishing season, the number of days fishing operations, the composition of the catch, and the size of the fish caught for each fishing gear. Complete results in table.2.

Table 2 analysis results show purse seine and line fishing occupy the priority for the category of the length of the fishing season, the composition of fish caught, purse seine and gill net at the priority; for the fishing trip length and size of fish caught, purse seine in the priority.

Table 2 - Assessment of Biological Analysis

\begin{tabular}{|c|c|c|c|c|c|c|c|c|c|c|c|}
\hline \multirow[b]{2}{*}{ No } & \multirow[b]{2}{*}{ Fishing Gear } & \multicolumn{8}{|c|}{ Biological Aspects } & \multirow[b]{2}{*}{$\mathrm{V}(\mathrm{A})_{2}$} & \multirow[b]{2}{*}{ OP } \\
\hline & & $\mathrm{X} 1$ & $\mathrm{~V}_{1}\left(\mathrm{X}_{1}\right)$ & $\mathrm{X} 2$ & $\mathrm{~V}_{2}\left(\mathrm{X}_{2}\right)$ & X3 & $\mathrm{V}_{3}\left(\mathrm{X}_{3}\right)$ & $X 4$ & $\begin{array}{c}\mathrm{V}_{4} \\
\left(\mathrm{X}_{4}\right)\end{array}$ & & \\
\hline 1 & Lift net & 7 & 0,00 & 1,62 & 0,46 & 4,69 & 0,10 & 1,55 & 0,00 & 0,56 & 5 \\
\hline 2 & Gill net & 9 & 0,67 & 1,17 & 0,11 & 5,00 & 1,00 & 1,67 & 0,12 & 1,90 & 2 \\
\hline 3 & Purse seine & 10 & 1,00 & 2,33 & 1,00 & 5,00 & 1,00 & 2,50 & 1,00 & 4,00 & 1 \\
\hline 4 & Line fishing & 10 & 1,00 & 1,02 & 0,00 & 4,65 & 0,00 & 1,96 & 0,43 & 1,43 & 4 \\
\hline 5 & Beach seine & 9 & 0,67 & 1,39 & 0,28 & 4,83 & 0,51 & 1,62 & 0,07 & 1,53 & 3 \\
\hline
\end{tabular}

Source: Research data processed, 2019.

Note:

X1: Length of capture season (month);

$\mathrm{X} 2$ : Length of arrest day;

X3: Many types of fish caught;

X4: Size of fish that are often caught;

$\mathrm{Vi}(\mathrm{Xi})$ : The value function of alternative $\mathrm{Xi}$;

$V(A)$ : The value function of alternative $A$, which is the sum of $\mathrm{Vi}(\mathrm{Xi})$;

OP: Priority order. 
Standardize the biological aspect criteria by using the value function against all assessment criteria, purse seine in the first order, the second sequence of gill nets, the third order of beach seine, the four a line fishing, and the five lifts net.

The social aspects include evaluating the labor absorption of each fishing gear, the monthly income of fishermen, the level of technological mastery, and the fishing gear received by the community (Table 3 ).

Table 3 - Assessment of social aspects analysis

\begin{tabular}{|c|c|c|c|c|c|c|c|c|c|c|c|}
\hline \multirow{2}{*}{ No } & \multirow{2}{*}{ Fishing Gear } & \multicolumn{8}{|c|}{ Social Aspetc } & \multirow{2}{*}{$\mathrm{V}(\mathrm{A})_{3}$} & \multirow{2}{*}{ OP } \\
\hline & & $\mathrm{X} 1$ & $\mathrm{~V}_{1}\left(\mathrm{X}_{1}\right)$ & $\mathrm{X} 2$ & $\mathrm{~V}_{2}\left(\mathrm{X}_{2}\right)$ & $\mathrm{X} 3$ & $\overline{V_{3}\left(X_{3}\right)}$ & $\mathrm{X} 4$ & $\overline{V_{4}\left(X_{4}\right)}$ & & \\
\hline 1 & Lift net & 1,45 & 0,41 & 1.696 .305 & 0,84 & 4,97 & 0,9 & 4,0 & 0,8 & 2,91 & 2 \\
\hline 2 & Gill net & 1,25 & 0,20 & 1.571 .534 & 0,75 & 4,67 & 0,0 & 5,0 & 1,0 & 1,96 & 3 \\
\hline 3 & Purse seine & 2,00 & 1,00 & 1.940 .000 & 1,00 & 5,00 & 1,0 & 1,0 & 0,0 & 3,00 & 1 \\
\hline 4 & Line fishing & 1,06 & 0,00 & 449.348 & 0,00 & 4,94 & 0,8 & 5,0 & 1,0 & 1,82 & 4 \\
\hline 5 & Beach seine & 1,41 & 0,37 & 1.561 .373 & 0,75 & 4,76 & 0,3 & 1,0 & 0,0 & 1,39 & 5 \\
\hline
\end{tabular}

Source: Research data processed, 2019.

Note:

$\mathrm{X} 1$ : Absorption of labor;

$\mathrm{X} 2$ : Wages received by workers;

X3: The level of technological mastery;

X4: Tankers are accepted by the community;

$\mathrm{Vi}(\mathrm{Xi})$ : The value function of alternative $\mathrm{Xi}$;

$\mathrm{V}(\mathrm{A})$ : The value function of alternative $A$, which is the sum of $\mathrm{Vi}(\mathrm{Xi})$;

OP: Priority order.

The assessment of the superiority of fishing units based on social aspects places the purse seine ranking first in the categories of labor absorption, wages received, and the level of technological mastery. In the category of fishing gear accepted by the community, placing gill net and line fishing is the top priority. Standardization of social aspects criteria by using the value function against all assessment criteria, placing purse seine in first, second lift net, third-gill net, fourth fishing line, and fifth beach seine.

Determination of the order of priority to economic aspects based on business feasibility criteria. Table 4 shows an assessment of the economic aspects of overall business efficiency criteria after standardization, placing purse seine first, lift net second, beach seine third, Gill net and fourth line fishing.

Table 4 - Assessment of business analysis

\begin{tabular}{|c|c|c|c|c|c|c|c|c|c|}
\hline \multirow[b]{2}{*}{ No } & \multirow[b]{2}{*}{ Fishing Gear } & \multicolumn{6}{|c|}{ Economic Aspect } & \multirow[t]{2}{*}{$\mathrm{V}(\mathrm{A})_{4}$} & \multirow[t]{2}{*}{$\mathrm{OP}$} \\
\hline & & $\mathrm{X} 1$ & $\mathrm{~V}_{1}\left(\mathrm{X}_{1}\right)$ & $\mathrm{X} 2$ & $\mathrm{~V}_{2}\left(\mathrm{X}_{2}\right)$ & $\mathrm{X3}$ & $\mathrm{V}_{3}\left(\mathrm{X}_{3}\right)$ & & \\
\hline 1 & Lift net & Rp81.275.862 & 0,22 & Rp83.367.846 & 0,35 & Rp193.918.664 & 0,16 & 0,73 & 2 \\
\hline 2 & Gill net & Rp31.714.186 & 0,05 & Rp36.201.440 & 0,00 & Rp133.207.071 & 0,10 & 0,15 & 4 \\
\hline 3 & Purse seine & Rp307.142.857 & 1,00 & Rp172.461.064 & 1,00 & Rp1.102.859.571 & 1,00 & 3,00 & 1 \\
\hline 4 & Line fishing & Rp16.086.957 & 0,00 & Rp56.080.634 & 0,15 & Rp24.305.522 & 0,00 & 0,15 & 4 \\
\hline 5 & Beach seine & Rp33.125.000 & 0,06 & Rp44.871.075 & 0,06 & Rp139.180.500 & 0,11 & 0,23 & 3 \\
\hline
\end{tabular}

Source: Research data processed, 2019.

Note:

\author{
$X 1$ : Investment value; \\ X2: Rate of profit; \\ X3: Operating costs; \\ $V(A)$ : The value function of alternative $A$, which is the sum of $V i(X i)$; \\ OP: Priority ordr.
}

Investment efficiency includes the value of the Net Present Value (NPV), the value of the Benefit-Cost Ratio (Net B / C) and the value of the Internal Rate of Return (IRR\%). The results of the assessment of the Net Present Value (NPV) criteria put the purse seine on the priority, the second lift net, the third-gill net, the fourth fishing line, and the fifth beach seine. The IRR category (\%) places the line fishing, and beach seine capture unit at the priority and the Net B / C Ratio category places the life net at the priority. An assessment of the economic aspects of investment efficiency criteria is presented in Table 5. 
Standardization of economic aspects criteria by investment appraisal uses the value function against all valuation criteria, placing lift net first, second line fishing, third beach seine, fourth-gill net, and five purse seines.

Table 5 - Investment analysis valuation

\begin{tabular}{|c|c|c|c|c|c|c|c|c|c|}
\hline \multirow[b]{2}{*}{ No } & \multirow{2}{*}{ Fishing Gear } & \multicolumn{6}{|c|}{ Economic Aspect } & \multirow{2}{*}{$\mathrm{V}(\mathrm{A})_{5}$} & \multirow[b]{2}{*}{$\mathrm{OP}$} \\
\hline & & $\mathrm{X} 1$ & $\mathrm{~V}_{1}\left(\mathrm{X}_{1}\right)$ & $\mathrm{X} 2$ & $\mathrm{~V}_{2}\left(\mathrm{X}_{2}\right)$ & X3 & $\mathrm{V}_{3}\left(\mathrm{X}_{3}\right)$ & & \\
\hline 1 & Lift net & Rp216.700.920 & 0,62 & $98,14 \%$ & 0,72 & 1,5 & 1,00 & 2,34 & 1 \\
\hline 2 & Gill net & Rp92.049.103 & 0,19 & $99,16 \%$ & 0,74 & 1,3 & 0,33 & 1,26 & 4 \\
\hline 3 & Purse seine & Rp327.049.415 & 1,00 & $51,24 \%$ & 0,00 & 1,2 & 0,00 & 1,00 & 5 \\
\hline 4 & Line fishing & Rp55.762.592 & 0,06 & $116,25 \%$ & 1,00 & 1,4 & 0,67 & 1,73 & 2 \\
\hline 5 & Beach seine & Rp37.788.072 & 0,00 & $116,25 \%$ & 1,00 & 1,3 & 0,33 & 1,33 & 3 \\
\hline
\end{tabular}

Source: Research data processed, 2019.

Note:

$X 1: N P V$ value $>0$ (proper infestation), NPV $<0$ (improper infestation);

$X 2$ : IRR value $>12 \%$ bank interest rate (accepted), IRR $<12 \%$ interest rate (rejected);

$X 3$ : Net $B / C$ value $>1$ (proper infestation), Net $B / C<1$ (not feasible);

$\mathrm{Vi}(\mathrm{Xi)}$ : value function of alternative $X i$;

$V(A)$ : The value function of alternative $A$, which is the sum of $V i(X i)$;

OP: Priority order.

The purpose of determining the fishing unit is to identify a type of fishing gear that has good performance in terms of biological, technical, economic and social aspects so that it is a suitable fishing gear to be developed. The results of the scoring analysis conducted on 5 capture fisheries business units operated in the area of West Manggarai Regency both biologically, technically, socially and economically are presented in Table 6.

Table 6 - The results of the combined assessment of four aspects

\begin{tabular}{|c|c|c|c|c|c|c|c|c|c|c|c|c|c|}
\hline \multirow{2}{*}{ No } & \multirow{2}{*}{$\begin{array}{c}\text { Fishing } \\
\text { Gear }\end{array}$} & \multicolumn{10}{|c|}{ Assessment Criteria } & \multirow{2}{*}{$\begin{array}{l}\mathrm{V}(\mathrm{A}) \\
\text { total }\end{array}$} & \multirow{2}{*}{$\mathrm{OP}$} \\
\hline & & $\mathrm{V}(\mathrm{X})_{1}$ & $\mathrm{~V}(\mathrm{~A})_{1}$ & $\mathrm{~V}(\mathrm{X})_{2}$ & $\mathrm{~V}(\mathrm{~A})_{2}$ & $\mathrm{~V}(\mathrm{X})_{3}$ & $\mathrm{~V}(\mathrm{~A})_{3}$ & $\mathrm{~V}(\mathrm{X})_{4}$ & $\mathrm{~V}(\mathrm{~A})_{4}$ & $\mathrm{~V}(\mathrm{X})_{5}$ & $\mathrm{~V}(\mathrm{~A})_{5}$ & & \\
\hline 1 & Lift net & 2,68 & 0,85 & 0,56 & 0,00 & 2,25 & 0,66 & 0,73 & 0,20 & 2,34 & 1,00 & 2,72 & 2 \\
\hline 2 & Gill net & 1,34 & 0,25 & 1,90 & 0,39 & 1,20 & 0,19 & 0,15 & 0,00 & 1,26 & 0,19 & 1,03 & 4 \\
\hline 3 & Purse seine & 3,00 & 1,00 & 4,00 & 1,00 & 3,00 & 1,00 & 3,00 & 1,00 & 1,00 & 0,00 & 4,00 & 1 \\
\hline 4 & Line fishing & 1,27 & 0,22 & 1,43 & 0,25 & 1,99 & 0,55 & 0,15 & 0,00 & 1,73 & 0,54 & 1,56 & 3 \\
\hline 5 & Beach seine & 0,79 & 0,00 & 1,53 & 0,28 & 0,77 & 0,00 & 0,23 & 0,03 & 1,33 & 0,25 & 0,56 & 5 \\
\hline
\end{tabular}

Source: Research data processed, 2019.

Note:

$V(A)_{1}:$ Technical Aspects;

$V(A)_{2}$ : Biological Aspects;

$V(A)_{3}$ : Social Aspects;

$V(A)_{4}$ : Economic aspects of business analysis;

$V(A)_{5}$ : Economic aspects of investment analysis;

$V(A)$ Total: Amount of $V(A)$;

OP: Priority order.

Evaluation of technical, biological, social, economic aspects of business analysis criteria, and economic aspects of investment feasibility criteria put purse seine in the first place, lift net second, third line fishing, gill net fourth, and Beach seine fifth.

\section{DISCUSSION OF RESULTS}

The development of sustainable fishing tools is one alternative to fisheries strategies fishing. There are five main fishing tools used by fishermen in West Manggarai Regency today. The five fishing gears are lift net, gill net, purse seine, line fishing, and beach seine. This fishing gear is analyzed based on biological, technical, social and economic aspects. The results of the analysis place consecutive highest to lowest priorities, namely purse seine, lift net, fishing line, gill nets, and beach seine. 
The analysis of technical aspects of fishing gear shows that the purse seine is first followed by lift net, gill net, line fishing, and beach seine. Based on the criteria used, purse seine is the most productive fishing gear for pelagic fishing in West Manggarai Regency. Evidenced by the results of the analysis of productivity, purse seine occupies the highest production value of $361.67 \mathrm{~kg} / \mathrm{unit}$, higher than other fishing gear. beach seine ranks fifth, which means an unproductive fishing gear.

In addition to productivity, the criteria for the operational reach of the fishing gear place the purse seine in the order of priority, the operating distance of the purse seine ranges from 5-7 nautical miles from the coastline. This gives an illustration of the capture area of the purse seine is not limited. Based on the criteria of selectivity, purse seine occupies the top priority because purse seine only catches small pelagic fish species and no more than two types of fish.

Beach seine units are an option to reduce. Reducing the number of beach seine fishing units is done with the consideration of low productivity. Dahuri (2003) mentioned that to utilize the potential of available fish resources, technology transfer is needed from a traditional technology fishing unit to a modern technology fishing unit. The characteristic of catching technology with modern technology is high productivity.

Based on the assessment of biological aspects, purse seine ranks first, followed by gill net, beach seine, line fishing, and lift net. a purse seine is the highest order from the biological aspect compared to other fishing gear. Because purse seine is very selective in terms of how it is operated. Judging from the composition and size of fish catches obtained by purse seine, the average is worth catching. This is due to the size of the net mesh used in fishing to determine the size of the fish caught.

The results of observations are generally the size of the purse seine mesh used by fishermen is 3/4 ". The size of the mesh is uniform. The use of a uniform mesh allows the size of fish caught to be relatively uniform. Furthermore, the operation of the purse seine has no significant impact on habitat and biodiversity.

The results of research on social aspects show that purse seine is the best fishing gear in the first place. Furthermore, the lift net was ranked second, followed by gill net, line fishing, and beach seine. purse seine has the advantage of labor absorption and wages received by workers more than the other four fishing gear. Observation results, there were 15 workers at the time of operation of the fishing gear.

Excellence based on economic aspects shows that the purse seine is the order of top priority, followed by the lift net, the third beach seine, the fourth line fishing, and the gill net. Business analysis criteria that are considered are profitability, operational costs, and investment.

Excellence based on financial feasibility is the level of business profit. The results of observations on the standardization of economic aspects criteria by investment appraisal use the value function of all valuation criteria, placing the lift net first, second line fishing, third beach seine, fourth-gill net, and fifth purse seine.

The results of the combined analysis of the performance index matrix on biological, technical, social, and economic aspects, produce purse seine in the priority sequence, followed by lift net, line fishing, gill net, and beach seine.

From a technical aspect, purse seines have the far more operational reach, so the area for purse seine capture is not limited. The ability of purse seine is greater for catching pelagic fish compared to other fishing gear. Although purse seine catches small pelagic fish with a relatively low sale value compared to large pelagic fish. However, high production results in revenue from the sale of catches also greater. Furthermore, from the biological aspect of productivity criteria (CPUE), purse seine is superior compared to other capture equipment.

Seeing the potential of resources in the Savu Sea and the Flores Sea (outside the district management area) to date has not been utilized optimally. This potential provides considerable opportunities in the development of purse seine capture units in the West Manggarai Regency. Because the potential of fisheries in the high seas is still high and potential fishing areas for purse seine are quite available. 


\section{CONCLUSION}

The result research conducted five fishing units at the research location, the conclusion is: purse seine is a superior fishing unit that is feasible to be developed in the West Manggarai Regency based on consideration of biological, technical, social and economic aspects. Beach seine units need to be replaced with purse seine units to improve the welfare of fishermen by using superior gear.

\section{ACKNOWLEDGMENTS}

The authors gratefully acknowledged the financial support for this study provided by The Education Center, Marine and Fisheries Research and Human Resource Agency, Ministry of Marine Affairs and Fisheries, Indonesia.

\section{REFERENCES}

1. Antika, M., Mudzakir, A. K., \& Boesono, H. (2014). Financial Feasibility Analysis of Dogol Capture Fisheries Business at Ujung Batu Jepara Fish Landing Base (Ppi). Journal of Fisheries Resources Utilization Management and Technology, 3 (3), 200-207.

2. Dahuri Rohmin. 2003. Marine Biodiversity, Sustainable Development Assets. Gramedia: Jakarta

3. Damanik, M. R. S., Lubis, M. R. K., \& Astuti, A. J. D. (2016). Study of Ecosystem Approaches in Fisheries Management in Fisheries Management Areas (Wpp) 571 Malacca Strait, North Sumatra Province. Journal of Geography, 8 (2), 165-176.

4. Heriawan, Y. U. D. I. (2008). Allocation of Small Pelagic Fishing Units in Pandeglang Waters, Banten: Towards Controlled Fishing. Bogor Institute of Agriculture, Bogor.

5. Irham, I. (2013). Bio-Reproduction Aspects of Blue Lolosi (C. Caeulaureus) Landed At Ternate Fisheries Port, North Maluku Province. Agriculture: Journal of Fisheries Agribusiness, 6 (2), 53-61.

6. Iswara, K. W., Saputra, S. W., \& Solichin, A. (2014). Analysis of Biological Aspects of Turmeric Fish (Upeneus Spp) Based on the Distance of Operation of Catching Cantrang Fishing Equipment in the Waters of Pemalang Regency. Management Of Aquatic Resources Journal, 3 (4), 83-91.

7. Mahiswara, M., Budiarti, T. W., \& Baihaqi, B. (2016). Technical Characteristics of Trawl Ring Fishing Devices in the Waters of Apar Bay, Paser Regency, East Kalimantan. Indonesian Fisheries Research Journal, 19 (1), 1-7.

8. Septifitri, S., Monintja, D. R., Wisudo, S. H., \& Martasuganda, S. (2010). Fisheries Infrastructure Needs Analysis In Order To Capture Fisheries Development Based On Commodities Of South Sumatra Province. Fisheries Science: Indonesian Journal of Fisheries Science and Technology, 5 (2), 8-13.

9. Setiawan, I., Monintja, D. R., Nikijuluw, V. P., \& Sondita, M. F. A. (2007). Analysis of Regional Fishing Dependence as a Basis for Implementing Fisheries Empowerment Program Case Study in Cirebon and Indramayu Regencies.

10. Suman, A. (2017). Dogol Shrimp Fishing Equipment (Metapenaeus Ensis De Haan) That Is Eligible Developed In Cilacap and Surrounding Waters. Indonesian Fisheries Research Journal, 12 (2), 129-137.

11. Syaukani, M., Sondita, M. F. A., Monintja, D., Fauzi, A., \& Nikijuluw, V. P. H. (2017). Classification of Fisheries Port-Based Fishery Industry Centers: Cases in Belitung Regency. Journal of Indonesian Fisheries Policy, 2 (1), 1-14.

12. Wiadnya, D. G. R., Djohani, R., Erdmann, M. V., Halim, A., Knight, M., Mous, P. J. \& Soede, L. P. (2017). Policy Review of Capture Fisheries Management in Indonesia: Towards the Establishment of Marine Protected Areas. Indonesian Fisheries Research Journal, 11 (3), 65-77.

13. Wulandari, U., Simbolon, D., \& Wahju, R. I. (2017). Appropriate Fishing Unit Selection on Enggano Island, Bengkulu Province. Albacore, 1 (1). 